Боженко Наталія Василівна кандидат юридичних наук, суддя Дніпропетровського окружного адміністративного суду, вул. Академіка Чекмарьова, 5, м. Дніпро, 49000, тел.: (098) 038-15-22, e-mail: IvanovS@email.ua, https://orcid.org/0000-0002-7035-7182

Легеза Свген Олександрович доктор юридичних наук, професор, професор кафедри адміністративного та митного права, Університет митної справи та фінансів, вул. Телевізійна, 12, 49005, м. Дніпро, офіс 37, тел.: (098) 038-15-22, e-mail: yevhenleheza@gmail.com, https://orcid.org/0000-0001-9134-8499

\title{
УДОСКОНАЛЕННЯ ПРАВОВОЇ ОСНОВИ РЕГУЛЮВАННЯ МЕДІАЦІЇ В АДМІНІСТРАТИВНОМУ СУДОЧИНСТВІ
}

Анотація. У статті розглянуто проблеми та перспективи вдосконалення адміністративно-правового забезпечення медіації, його відповідності національній правовій системі та стандартам Європейського Союзу, а також надано дієві пропозиції щодо внесення змін до нормативно-правових актів, які регламентують роботу у даному напрямі.

3 метою належного введення медіації у правове поле; забезпечення захисту від звинувачень у корупції для державних службовців та представників судової системи, які безпосередньо використовують медіацію або рекомендують сторонам звертатись до медіації при врегулюванні адміністративних спорів; захисту медіатора шляхом заборони допитувати його як свідка; забезпечення одноманітного розуміння конфіденційності інформації в медіації; сприяння становленню професії медіатора та ринковому розвитку сфери медіації та інших чинників, в Україні необхідно якнайшвидше доопрацювати, прийняти та ввести в дію Закон України «Про медіацію». Цей документ не повинен містити ризиків щодо створення корупційних схем у сфері медіації, які завдадуть шкоди репутації послуги та процесу її впровадження, як-от: єдиний реєстр, спеціальний статус медіаторів у базовому законі, суттєві фінансові компенсації сторонам, що звертаються до суду після неуспішної медіації, один орган самоврядування для медіаторів.

Маємо констатувати, що на сьогоднішній момент медіація в Україні існує «на громадських засадах». Загальна кількість конфліктів, які було вирішено із застосуванням ADR-процедур незрівнянно менша, ніж кількість спорів вирішених у традиційному, судовому порядку. Можливо, законодавче закріплення медіації підвищить довіру до даного інституту і медіація зможе стати ефективним інструментом вирішення спорів в Україні.

Ключові слова: медіація, апробація, імплементація, спрощений порядок, роз'яснення. 
Bozhenko Natalia Vasylivna Candidate of Law, Judge of the Dnipropetrovsk District Administrative Court, 5, Akademika Chekmareva St., Dnipro, 49000, tel.: (098) 038-15-22, e-mail: IvanovS @email.ua, https://orcid.org/0000-0002-7035-7182

Leheza Yevhen Oleksandrovych Doctor of Law, Professor, Professor of the Department of Administrative and Customs Law, University of Customs and Finance, Television St., 12, office 37, Dnipro, 49005, tel.: (098) 038-15-22, e-mail: yevhenleheza@gmail.com, https://orcid.org/0000-0001-9134-8499

\title{
IMPROVEMENT OF THE LEGAL BASIS OF MEDIATION REGULATION IN ADMINISTRATIVE JUDICIARY
}

\begin{abstract}
The article considers the problems and prospects of improving the administrative and legal support of mediation, its compliance with the national legal system and standards of the European Union, as well as effective proposals for amendments to regulations governing the work in this area.

In order to properly introduce mediation in the legal field; providing protection against allegations of corruption for civil servants and members of the judiciary who directly use mediation or encourage parties to seek mediation in the settlement of administrative disputes; protection of the mediator by prohibiting the interrogation of him as a witness; ensuring a uniform understanding of the confidentiality of information in mediation; promoting the formation of the profession of mediator and market development of mediation and other factors, in Ukraine it is necessary to finalize, adopt and implement the Law of Ukraine "On Mediation" as soon as possible. This document should not contain risks of creating corrupt schemes in the field of mediation, which would damage the reputation of the service and the process of its implementation, such as: a single register, special status of mediators in the basic law, significant financial compensation to parties after unsuccessful mediation. , one selfgoverning body for mediators.

We must state that at present mediation in Ukraine exists "on a voluntary basis." The total number of disputes that have been resolved using ADR procedures is incomparably less than the number of disputes resolved in the traditional, judicial order. It is possible that the legislative consolidation of mediation will increase the credibility of this institution and mediation will be able to become an effective tool for resolving disputes in Ukraine.
\end{abstract}

Keywords: mediation, approbation, implementation, simplified procedure, explanation.

Постановка проблеми. На сьогодні в Україні медіація, як професійна діяльність, потребує певної теоретичної основи, акумуляції та апробації всіх наукових розробок, експериментальних даних, введення єдиного понятійного апарату, що були накопичені досвідом зарубіжних фахівців з початку розвитку медіації.

Актуальність удосконалення адміністративно-правового забезпечення медіації зумовлюється тим, що іiі ефективне застосування у рамках 
адміністративного судочинства дозволить вирішити важливу для сучасної системи адміністративних судів проблему - розвантажити їх від надмірного обсягу справ, що перебувають у їх провадженні.

Аналіз останніх досліджень і публікацій. Нині завдяки науковим працям В. Б. Авер'янова, Н. О. Армаш, К. К. Афанасьєва, Ю. П. Битяка, М. Ю. Віхляєва, Н. А. Галабурди, В. М. Гаращука, I. П. Голосніченка, С. В. Ківалова, I. Б. Коліушка, Т. О. Коломоєць, В. К. Колпакова, А. Т. Комзюка, О. В. Кузьменко, Є. В. Курінного, С. О. Легези, Д. В. Лученка, П. С. Лютікова, А. А. Манжули, Р. С. Мельника, В. П. Тимощука та інших вчених досліджено питання щодо примирення конфліктуючих сторін в адміністративному судочинстві.

Формування інституту медіації та його застосування на практиці відображено у роботах зарубіжних вчених, таких як: Дж. Аргіс, К. Бернард, Х. Бесемер, Л. Боуль, М. Пель, Д. Річбелл, Е. Тейлор, А. Троссен, Г. Шварц та ін. Дослідженню порядку проведення медіації, вимог до посередника приділяли увагу М. В. Гвоздирєва, Д. Б. Слісеєв, С. І. Калашникова, О. С. Карпенюк, О.М. Кузбагаров, М. А. Романенко, А. Д. Сідельников, Ю. М. Старилов, А. С. Хищенко. Поширення альтернативних форм врегулювання спорів на публічно-правову сферу та аналіз застосування експериментальної процедури досудового врегулювання спорів, віднесених до юрисдикції адміністративних судів, висвітлено у роботах В. М. Бевзенка, О. В. Белінської, С. С. Білуги, Н. Л. Бондаренко-Зелінської, Д. Л. Давиденка, О. М. Михайлова, Т. О. Подковенко, Ю. Д. Притики, Г. Й. Ткача, Г. О. Ульянова, А. М. Шохіна, К. А. Шумової та ін.

Викладене свідчить про актуальність теми дисертації, їі важливе теоретичне i практичне значення щодо подальшого розвитку адміністративного права та удосконалення законодавства про адміністративне судочинство відповідно до конституційних та міжнародно-правових стандартів.

Метою статті $\epsilon$ розкриття особливості удосконалення правової основи регулювання медіації в адміністративному судочинстві.

Виклад основного матеріалу. Так, відповідно до даних узагальнення судової практики адміністративних судів за період 32012 р. по 2021 р. у провадженнях місцевих адміністративних судів перебувало 6449087 справ. 3 2012 р. по 2021 р. ними було розглянуто 1267540 адміністративних справ, 3 яких лише близько 0,05 \% закінчилися примиренням сторін (667 справ). Зокрема, у 2012 р. з 497097 розглянутих адміністративних справ лише 102 закінчилися примиренням сторін (0,02\%); у 2013 р. 3285208 справ - 125 (0,04\%); у 2014 р. 3 232449 справ - 148 (0,06 \%); у 2015 р. 3204104 справ - лише 175 (0,08 \%). У першому півріччі 2016 р. адміністративними судами було розглянуто 46682 справи і лише 117 з них закінчилися примиренням сторін (0,25 \%) [1]. Усе це свідчить про підвищення інтересу учасників адміністративних спорів до інституту примирення сторін, проте кількість справ, що закінчуються примиренням, наразі залишається низькою. Для прикладу, у Великобританії i США близько 80 \% адміністративних спорів урегульовується мирним шляхом. 
Зважаючи на те, що на сьогодні в Україні немає законодавчого закріплення медіації в системі адміністративного судочинства, можна скористатися іншим шляхом та розглядати медіацію як частину адміністративної діяльності судів. Тут також слід розглядати декілька варіантів. Перший - медіатором виступає спеціально підготовлений працівник апарату суду. В такому випадку медіація, в принципі, не $\epsilon$ частиною судочинства, а лише частиною «документообігу». Ми вбачаємо можливість реалізації такого підходу шляхом збільшення штатної чисельності працівників апарату суду у відповідному співвідношенні до кількості суддів та з урахуванням роботи спеціалізованих колегій із розгляду справ, а також шляхом розвитку даної компетенції спеціаліста-медіатора. Другий варіант - здійснення медіації суддею, наділеним адміністративними повноваженнями (саме в рамках адміністративної діяльності судді), який, при цьому, звільнений від обов'язку здійснювати судочинство в даній адміністративній справі.

Нам імпонує точка зору С. І. Калашникової, яка вважає, що для того, щоб забезпечити права добросовісних учасників процедури медіації, слід передбачити спрощений порядок приведення медіативної угоди до виконання, розвиваючи ідею про те, що нотаріально засвідчити медіативну угоду і визнати за нею виконавчу силу найдоцільніше. Це дозволить забезпечити реалізацію досягнутих в медіації домовленостей, дотримуючись принципів як юрисдикційної, так і неюрисдикційної діяльності [2].

Д. Л. Давиденко з цього приводу зазначає, що у ряді країн з розвиненими правовими системами, що мають тривалу історію еволюційного розвитку, склалися механізми сприяння спрощеному приведенню у виконання мирових угод, досягнутих сторонами у відсутність судового процесу [3]. Суди в них уповноважені надавати виконавчу силу таким позасудовим мировим угодам. Це надає сторонам ряд переваг у порівнянні 3 тією ситуацією, коли мирова угода затверджується після початку судової процедури.

Зазначимо, як приклад, що суддя-посередник (медіатор) у Канаді може відмовитися від застосування процедури досудового врегулювання адміністративних спорів, якщо він: не бачить перспектив застосування процедури досудового врегулювання адміністративних спорів, оскільки характер спору свідчить про неможливість узгодження позиції сторін; усвідомлює, що одна із сторін затягує час або використовує процедуру досудового врегулювання спорів недобросовісно (з метою з'ясування позиції іншої сторони, отримання інформації про наявні докази, що потім використає в судовому засіданні) [4]. Нам імпонує такий підхід і вважаємо за доцільне знайти відповідне закріплення в українському законодавстві.

На думку А. М. Кузбагарова, 3 метою надання оперативного характеру праву сторін на примирення їх у виконавчому провадженні, необхідно розширити суб'єктний склад, який наділений правом затверджувати угоду про примирення i надавати йому юридично процесуальне значення, та наділити такими повноваженнями нотаріусів [5].

А. К. Большова, обговорюючи перспективи впровадження позасудових способів вирішення спорів, вважає, що досудове врегулювання має бути 
обов'язковим, тобто воно повинне поширюватися на усі категорії справ; при цьому сторони повинні мати право вибирати один із способів, не замикаючись тільки на посередництві або претензійному порядку [6].

Нам більше імпонує думка Д. І. Бекяшева, який справедливо вказує, що суд повинен роз'яснювати обом сторонам переваги мирової угоди, роз'яснюючи їм можливі варіанти вирішення справи, роблячи акцент на тому, що які-небудь причини: брак доказів у сторін, неможливість їх виявлення, недотримання терміну - можуть вплинути на винесення такої судової ухвали, коли уся тяжкість процесу, усі наслідки випадкових обставин, ляжуть на одну сторону; при мировій угоді можливий сприятливіший результат справи, де кожній стороні треба буде виконати тільки частину домагань опонента [7].

Неможливо не погодитися 3 позицією С. І. Калашникової, яка пропонує надати суду право направляти учасників судового процесу на інформаційну зустріч 3 медіатором, під час якої сторонам спору необхідно роз'яснювати переваги медіативної процедури у порівнянні з судовим розглядом і пропонувати взяти участь в примирливій процедурі [2].

На наш погляд, якщо законодавець не окреслить коло обов'язково медіабельних справ, то зустрічі 3 медіатором за позовами, в яких суд переконаний про необхідність примирення сторін, що сперечаються, повинні мати імперативний характер. Окрім того, доцільно встановити імперативні терміни проведення процедур примирення по окремих категоріях справ. При цьому, зазначені терміни не повинні перевищувати терміни розгляду справ судами (по більшості категорій справ - 2 місяці).

У той же час, вимога дотримання обов'язкового досудового порядку по усіх категоріях справ може мати і негативний ефект: сторона, що отримала претензію, вживатиме негайні заходи щодо приховування майна і до моменту пред'явлення позову буде неплатоспроможним боржником. У даному питанні потрібний розумний баланс. Враховуючи викладене, ми вважаємо можливим встановити обов'язкове досудове врегулювання наступних категорій справ: трудові спори про відновлення на роботі і стягнення заробітної плати (можливе залучення профспілок, комісій з трудових спорів, державних інспекцій 3 питань праці); трудові спори про відшкодування збитку, заподіяного під час виконання трудових обов'язків (можливе залучення профспілок, комісій з трудових спорів, державних інспекцій 3 питань праці); позови про відшкодування шкоди, заподіяної життю і здоров'ю, а також шкоди, заподіяної смертю годувальника; позови про виселення; позови про визнання права власності на житло в силу приватизації; позови про визнання права власності на самовільні будівлі (необхідно заздалегідь передбачити заходи по легалізації побудови шляхом звернення в орган місцевого самоврядування із заявою про введення об'єкта в експлуатацію); позови про визначення порядку користування майном; позови про розділ загального майна, виділення 3 нього долі; позови про захист інтелектуальної власності; позови про захист прав споживачів; позови про захист честі, гідності і ділової репутації; позови про стягнення сум за договором позики, кредитним договором; позови про стягнення податків і зборів; позови про стягнення заборгованостей по комунальних платежах; позови, пов'язані iз 
спадкоємством майна (до досудового вирішення спору можливе залучення нотаріусів); позови про відшкодування збитку від ДТП; заяви про розірвання шлюбу; заяви по спорах, пов'язаних з вихованням дітей.

Також, вважаємо за доцільне запровадження донормативних документів діяльності судів, в якості одного 3 критеріїв оцінки діяльності судді - кількості затверджених ним мирових угод. При розробці цього критерію повинні враховуватися такі загальновизнані міжнародні акти як Основні принципи ООН, що стосуються незалежності судових органів (1985 р.), Рекомендація № R (94) 12 Комітету міністрів Ради Свропи про незалежність, ефективність і роль суддів (1994 р.), Свропейська хартія про статус суддів (1998 р.), Бангалорські принципи поведінки суддів (2006 р.), норми внутрішнього українського законодавства.

I хоча наразі в Україні проводиться активна робота над законодавчим врегулюванням медіації, проте, як свідчить аналіз зарубіжного досвіду, існують також i деякі обгрунтовані побоювання 3 приводу намагань законодавчо врегулювати медіацію в Україні. Це пов’язано, у першу чергу, з гіпертрофованим адмініструванням суспільного життя в нашій державі. Так, на думку правознавців, будь-яка сфера діяльності, відносини в якій береться регулювати держава, врешті-решт стає надмірно зарегульованою, а іноді навіть припиняє розвиватися (наприклад, ситуація 3 медіацією в Румунії - до прийняття відповідного закону медіатори розглядали більше 1500 справ на рік, а після прийняття - лише декілька десятків).

Слід зазначити, що в державах ЄС медіація розглядається не тільки як спосіб альтернативного вирішення спорів, де вже виник конфлікт, але і як спосіб, який використовується для запобігання виникнення спору (конфлікту) в майбутньому, що, безумовно, розширює межі застосування медіації. Зважаючи на те, що процесуальна гнучкість процедури медіації дозволяє застосовувати посередництво в різних ситуаціях, відсутнє чітке регулювання методів медіації. Законодавства практично всіх держав СС свідомо відмовилися від спроби регулювання методів як таких. Самі сторони спору, а також посередники (медіатори) мають право вибору найбільш дієвих способів для вирішення спірних ситуацій в кожному конкретному випадку, створюючи прецеденти. Більше того, у залежності від сфери застосування, можуть застосовуватися різні інструменти (методи) примирення.

Україна також має власні традиції позасудового врегулювання спору на основі порозуміння сторін, а тому потрібен лише поштовх для розвитку комплексної системи врегулювання спорів, що дозволить досягти цілей, визначених Стратегією реформування судоустрою, судочинства та суміжних правових інститутів на 2015-2020 роки.

На наш погляд, будь-яка модель медіації у судовому процесі хоча і може розвантажити судову систему, але, на сьогодні, на жаль, суто формально, тому що запровадження медіації за відсутності звички у громадян вирішувати свої спори самостійно може призвести до нівелювання іміджу медіації i невиправдання очікувань громадян, у свою чергу, може бути завдано невиправданої шкоди усьому процесу впровадження медіації в Україні. 
Висновки. Підсумовуючи, маємо констатувати, що на сьогоднішній момент медіація в Україні існує «на громадських засадах». Загальна кількість конфліктів, які було вирішено із застосуванням ADR-процедур незрівнянно менша, ніж кількість спорів вирішених у традиційному, судовому порядку. Можливо, законодавче закріплення медіації підвищить довіру до даного інституту i медіація зможе стати ефективним інструментом вирішення спорів в Україні.

3 метою належного введення медіації у правове поле; забезпечення захисту від звинувачень у корупції для державних службовців та представників судової системи, які безпосередньо використовують медіацію або рекомендують сторонам звертатись до медіації при врегулюванні адміністративних спорів; захисту медіатора шляхом заборони допитувати його як свідка; забезпечення одноманітного розуміння конфіденційності інформації в медіації; сприяння становленню професії медіатора та ринковому розвитку сфери медіації та інших чинників, в Україні необхідно якнайшвидше доопрацювати, прийняти та ввести в дію Закон України «Про медіацію». Цей документ не повинен містити ризиків щодо створення корупційних схем у сфері медіації, які завдадуть шкоди репутації послуги та процесу їі впровадження, як-от: єдиний реєстр, спеціальний статус медіаторів у базовому законі, суттєві фінансові компенсації сторонам, що звертаються до суду після неуспішної медіації, один орган самоврядування для медіаторів.

\section{Лimepamypa:}

1. Перспективи впровадження процедури медіації в адміністративному судочинстві України. URL: http://www.voas.gov.ua/?action=news\&id_news=111

2. Калашникова С. И. Медиация в сфере гражданской юрисдикции: автореф. дисс. ... канд. юрид. наук. Екатеринбург, 2010. С. 19.

3. Давыденко Д. Л. Содействие примирению сторон в странах западной Европы: обеспечение исполнения медиативных и иных мировых соглашений. URL: http://www.iurisprudentia.ru/files

4. Аргіс Дж. Довідник з питань врегулювання судових спорів за допомогою судді (для канадських суддів та адвокатів). URL: http://archive.nbuv.gov.ua/e-journals/FP/20124/10govkpu.pdf.

5. Кузбагаров А.Н. Примирение сторон по конфликтам частноправового характера: дисс. ... д-ра юрид. наук. СПб., 2006. С. 320.

6. Большова А.К. Концепция развития законодательства о несудебных процедурах разрешения споров. Концепция развития российского законодательства. М., 2010. С. 672, 676.

7. Бекяшева Д. И. Примирительное разбирательство на стадии подготовки дела будущее гражданского процесса. Правовые исследования: новые подходы: сборник статей факультета права НИУ ВШЭ. М., 2012. С. 465-466.

\section{References:}

1. Perspektyvy vprovadzhennia protsedury mediatsii $\mathrm{v}$ administratyvnomu sudochynstvi Ukrainy [Prospects for the implementation of the mediation procedure in the administrative proceedings of Ukraine]. Retrieved from http://www.voas.gov.ua/?action=news\&id_news=111 [in Ukrainian].

2. Kalashnykova S. Y. (2010). Medyatsyia v sfere hrazhdanskoi yurysdyktsyy [Mediation in the field of civil jurisdiction]. avtoref. dyss. ... kand. yuryd. nauk. - author. diss. ... Cand. jurid. sciences. Ekaterinburg [in Russian]. 
3. Davudenko D. L. (2011). Sodeistvye prymyrenyiu storon v stranakh zapadnoi Evropы: obespechenye yspolnenyia medyatyvnыkh y ynыkh myrovukh sohlashenyi. [Promoting the reconciliation of the parties in Western Europe: ensuring the implementation of mediation and other settlement agreements]. Retrieved from http://www.iurisprudentia.ru/files. [in Russian].

4. Arhis Dzh. Dovidnyk z pytan vrehuliuvannia sudovykh sporiv za dopomohoiu suddi (dlia kanadskykh suddiv ta advokativ) [Handbook of Judicial Assistance (for Canadian judges and lawyers)]. Retrieved from http://archive.nbuv.gov.ua/e-journals/FP/2012-4/10govkpu.pdf. [in Ukrainian].

5. Kuzbaharov, A.N. (2006). Prymyrenye storon po konflyktam chastnopravovoho kharaktera [Reconciliation of the parties to conflicts of a private law nature]. dyss. ... d-ra yuryd. nauk - diss. ... Dr. jurid. sciences. SPb.[in Russian].

6. Bolshova, A.K. (2010). Kontseptsiya razvitiya zakonodatelstva o nesudebnykh protsedurakh razresheniya sporov. Kontseptsiya razvitiya rossiyskogo zakonodatelstva [Concept for the development of legislation on non-judicial dispute resolution procedures. Concept for the development of Russian legislation]. (pp 672-676). M. [in Russian].

7. Bekiasheva D. Y. (2012). Prymyrytelnoe razbyratelstvo na stadyy podhotovky dela budushchee hrazhdanskoho protsessa [Conciliation proceedings at the stage of preparation of the case - the future of the civil procedure]. Pravovue yssledovanyia: novue podkhodu: sbornyk statei fakulteta prava NYU VShЭ - Legal Research: New Approaches: Collection of Articles of the Faculty of Law of the National Research University Higher School of Economics. (pp 465-466). M. [in Russian]. 